\title{
IDIOM MUSIK KLASIK DI GEREJA KARISMATIK
}

\author{
M. Hari Sasongko \\ Prodi Musik Gereja, Sekolah Tinggi Theologia Abdiel \\ Jl. Pangeran Diponegoro No.233, Ungaran, Kabupaten Semarang, Jawa Tengah 50511 \\ michaelhari.sas@gmail.com
}

\begin{abstract}
Church music has long history and experiences in its periods. It began when they, the believers, mentioned themselves as the "Christian". From the time that phenomenon the christians commenced their act of devotion tradition included their musical tradition of worship. The existence of church music more developed till Middle Age or Dark Age Period. It was dominantly covering to others music genre. At the Renaisance Period, the church reformation movement occured and it was pioneered by Martin Luther. Western music changed at the time. Luther changed of scene; He changed the tradition of Catholic church that used Latin lirics to folk language; He changed the gregorian chant tradition with folksong. The phenomenon was the first time of event of inculturation in world history of music after it undergone stagnancy during the authorization of Roman empire, especially when Pope Gregory created the standarization to all christian music. At the present day we are familiar with charismatic music tradition which is developed from American music tradition. It has a characteristic which is used as the band instrument in praise and worship by christian believers. But sometimes, the believers also use arpeggio or broken-chord as the main charracter on Classical Period in part the way of Western music history. Pass through the reasearch, the reasearcher look into the idioms are used in praise and worship in charismatic church. The reasearcher found that the using of idiom in Classical Period has enriched the nuance of music aesthetic in praise and worship.
\end{abstract}

Keywords: Classical Period; arpeggio; charismatic; praise and worship

\section{Pendahuluan}

Kristen Kharismatik adalah aliran agama Kristen yang menonjolkan atau bercirikan karunia rohani atau gerakan roh (Karl, 1975, p. 184-185). Kata "Kharismatik" berasal dari bahasa Yunani; $\chi \alpha ́ \rho ı \sigma \mu \alpha=$ Kharisma (tunggal) atau Kharismata (jamak) yang artinya karunia roh (Samuel, 2006). Pandangan ini berdasar pada Alkitab Perjanjian Baru yang secara spesifik terdapat dalam Surat Roma 1:11, 5:15-16, 6:23, 11:29, 12:6, Surat I Korintus 1:7, 7:7, 12:4, 9, 28, 30-31, Surat II Korintus 1:11, Surat I Timotius 4:14, Surat I Timotius 1:6 dan Surat I Petrus 4:10 (Sugiri, 2006). Hal ini dipercaya sebagai pekerjaan Yesus Kristus dalam Roh Kudus.

Aliran ini sebenarnya sudah ada sejak zaman reformasi yang dikenal dengan Anabaptisdi Eropa, yakni gerakan yang lahir saat reformasi Lutheran di abad ke-16. Penganutnya sudah ada sejak abad ke-2 yang dikenal dengan montanisme, namun baru muncul sebagai gereja di abad dua puluhan (John, 1982). Kemunculannya menimbulkan reaksi dari agama Katolik, Presbiterian, Kongregasional, Anglikan dan sebagainya 
(Matthew, 2008, p. 221). Gerakan ini ada yang menjadi gereja, namun juga ada yang tetap menjadi gerakan atau sekte, atau juga disebut Gerakan Pentakostal Baru, atau Gerakan Zaman Baru, atau Gerakan Gelombang ke Tiga jika dilihat dari ajaran teologinya (Albineno, 1976, p. 17).

Gerakan Kharismatik yang merupakan kelanjutan dari kegerakan Pentakosta memiliki banyak kemiripan antara lain keduanya mengakui kuasa Roh Kudus dan Kesembuhan Ilahi, dan keduanya dikenal dengan gaya kotbah yang berapi-api. Walaupun sangat mirip sehingga terkadang sulit membedakan aliran Kharismatik ini dengan aliran Pentakosta yang lahir jauh lebih dahulu daripadanya dan yang menjadi inspirasinya, ada beberapa aspek yang membedakan keduanya seperti kebanyakan Kharismatik menolak keutamaan glossolalia atau bahasa roh yang diberlakukan oleh Pentakosta dan banyak Kharismatik yang seringkali tetap berada di denominasinya sendiri tanpa mendirikan gereja baru, seperti Kharismatik Katolik di Gereja Katolik Roma.

Pentakostalisme dan Kharismatisme tidak lepas dari pendahulunya yaitu Methodisme. Methodisme merupakan aliran yang diajarkan oleh dua bersaudara John Wesley dean Charles Wesley. John Wesley diberi julukan sebagai "Bapak Pentakolisme" karena banyak ajaran dan gagasan serta pendekatan teologisnya diadopsi oleh Pentakolisme.

Gerakan Kharismatik ini berkembang dengan sangat cepat dan penyebarannya sangat dirasakan di beberapa negara seperti Eternal Grace, Newfrontiers, Vineyard Movement, dan Sovereign Grace Ministries. Di Indonesia sendiri, terutama di kota besar seperti Jakarta dan sekitarnya juga dirasakan sangat hebat, seperti Gereja Mawar Sharon (GMS), Charismatic Worship Service (CWS), Gereja Bethany Indonesia (Bethany), Gereja Bethel Indonesia (GBI), Gereja Duta Injil, Gereja Rumah Doa Segala Bangsa (RDSB), Gereja Yesus Kristus Tuhan (Abbalove Ministries), Gereja Tiberias Indonesia (GTI Tiberias), Gereja Bethel Tabernakel (GBT), Gereja Kemenangan Iman Indonesia (GKII), Gereja Jemaat Kristen Indonesia (GJKI). Ada dua gerakan yang memiliki kontribusi sangat besar di Asia terhadap pertumbuhan aliran Kharismatik, yakni Assemblies of God dan Full Gospel Businessmen Fellowship di Amerika (Samuel, 2006; Sugiri, 2006).

Dalam sebuah tata ibadah Kristiani, ibadah dan musik tidak dapat dipisahkan, ibarat dua buah sisi mata uang. Ibadah Kristen menurut Hoon adalah pernyataan diri Allah sendiri dalam Yesus Kristus dan tanggapan manusia terhadapNya. Menurut Luther bahwa tidak ada satu pun yang terjadi di dalam ibadah kecuali bahwa Tuhan kita yang pengasih 
itu sendiri berbicara kepada kita melalui firmanNya yang kudus dan bahwa kita, pada gilirannya, berbicara kepadaNya melalui doa dan nyanyian pujian (White, 2002, p. 7-8).

Peran musik dalam kehidupan serta ibadah jemaat ada tertulis dalam Alkitab yaitu Kitab Mazmur 66:17 dan Kitab Efesus 5:19, namun setiap gereja memiliki peran, gaya musik dan porsi musik yang berbeda-beda dalam ibadah mereka. Perbedaan genre musik dalam musik gereja bukan menjadi masalah mendasar, tetapi lebih kepada muatan musik tersebut, sepanjang musik itu ditujukan untuk memuliakan Tuhan dan mendatangkan berkat bagi jemaat yang mendengarkannya supaya kerohanian mereka bisa bertumbuh.

Menurut John F. Wilson musik itu sendiri tidak mampu menjadikan seseorang menjadi Kristen, juga tidak membuat mereka menyembah. Dalam kenyataannya bagian pokok keberadaan musik gereja saat ini tidak memiliki perbedaan gaya dalam pelaksanaanya (aransemennya), tatanan fisiknya (instrumennya), dan untuk tujuan-tujuan yang lain, serta perbedaaannya terletak pada pengunaannya (Wilson, 1965, p. 17).

Menurut White (1990) fungsi utama musik gerejawi adalah untuk menambah dimensi keterlibatan ke dalam ibadah. Alasan mengapa musik membantu ibadah adalah bahwa musik merupakan medium yang lebih ekspresif dibandingkan dengan ucapan biasa, musik memungkinkan untuk mengekspresikan intensitas perasaan melalui kepelbagian dalam kecepatan, pola titik nada, keras lembut, melodi dan ritme, dan musik dapat, dan sering, menyampaikan intensitas yang lebih besar dalam perasaan dibanding kalau diekspresikan tanpa disertai musik.

Di awal kitab Kejadian (Kejadian 4:21) telah ditunjukkan bahwa Allah adalah Pencipta musik, sumber inspirasi musik dan menyukai musik. Pada zaman pemerintahan theokrasi, melalui para nabi, hakim dan imam, juga pada zaman raja-raja (1 Tawarikh 6:31-32 dan 1 Tawarikh 9:33), Allah memberi porsi yang banyak terhadap musik. Hal ini tidak berarti bahwa teologi/ doktrin/ firman tidak penting, namun betapa banyak, baik, dan sering seharusnya umat Tuhan mengucap syukur atas keselamatan yang telah diterima seperti yang dinasehatkan pemazmur dalam Kitab Mazmur 100:1-4.

Begitu pentingnya musik dalam gereja, sehingga tidak heran Martin Luther King (1483-1546) sebagai Bapak Reformasi Gereja, pernah berkata, "Music is a gift of God, not a gift of men," dan "After theology, we give the greatest honor to music; let it be music, we will make it as sacred as it needs be". Maksud ungkapan tersebut adalah musik merupakan pemberian dari Tuhan bukan pemberian manusia dan setelah teologia/ doktrin/ firman, mari kita beri penghargaan tertinggi kepada musik; biarlah ada musik, dan kita akan 
menguduskannya sebagaimana seharusnya. Allen dan Borror, penulis buku Worship Rediscovering The Missing Jewel (1952) mengatakan bahwa: “Allah menganugerahkan musik agar kita dapat menggunakan dan mengembangkannya untuk mengungkapkan kreativitas kita dalam penyembahan dan ibadah manusia kepada Allah”. Dari uraian tersebut maka penulis berkesimpulan bahwa umat Tuhan seharusnya serius terhadap musik, memanfaatkan musik secara positif dan menempatkannya sesuai proporsinya dalam gereja.

Perlakuan terhadap cara menyanyi jemaat dan musik yang digunakan dalam ibadah mengalami perkembangan, baik dari segi fungsi maupun strukturnya. Alkitab menuliskan peran musik dalam kehidupan serta ibadah jemaat, namun setiap gereja memiliki peran, gaya musik dan porsi musik yang berbeda-beda dalam ibadah mereka. Gereja tradisional misalnya dengan mazmur (Albineno, 2005, p. 70) saja yang kemudian berkembang dengan adanya himne (lihat Sevy, 1975, p. 48) yang diiringi dengan piano atau organ dan ibadah yang liturgikal, gereja GBKP (Gereja Batak Karo Protestan) dengan musik tradisional karo yang dimainkan melalui program musik keyboard, GKJ (Gereja Kristen Jawa) dengan musik gamelan dalam ibadahnya.

Musik yang digunakan dalam ibadah Kharismatik merupakan musik dengan gaya yang sangat berbeda dari gereja-gereja tradisional yang himne. Tata cara ibadah di gereja Kharismatik lebih dikenal dengan Pujian dan Penyembahan (praise and worship) yang dalam ibadahnya memiliki ciri khas lagu pujian yang sifatnya semangat atau antusiasme dan dinamis. Lagu penyembahannyapun menyentuh hati dengan aransemen dan genre musik Kristen pop atau kontemporer (Christian contemporary music) (Saragih, 1976, p. 76) yang juga diikuti dengan penyembahan dalam bahasa roh/glossolalia(Injil Yohannes $4: 24)$.

Musik dalam ibadah yang dilakukan oleh kalangan gereja-gereja Kharismatik ini sifatnya lebih spontan dan fleksibel, tidak dilakukan dengan struktur yang kaku, penggunaan tempo yang bervariasi, lagunya mudah disenandungkan dan mudah dipahami, berbeda dengan musik dalam ibadah gereja-gereja tradisional yang penyembahannya dilakukan dengan cara menyanyikan lagu-lagu dari buku-buku himne yang sudah lama dan digunakan sebatas aktivitas liturgikal (Schemann, 1965, p. 28) dengan pola ibadah yang teratur. Pola ibadah pujian dan penyembahan di gereja Kharismatik dipimpin oleh seorang pemimpin pujian (worship leader) yang di back up oleh beberapa penyanyi (singers) 
dengan menggunakan alat musik yang lebih dikenal dengan istilah combo band, yaitu alat musik yang terdiri dari keyboard, gitar, gitar elektrik, gitar bass elektrik dan drum.

Akan tetapi di dalam pelaksanaannya ibadah di gereja karismatik tidak selamanya menggunakan model atau gaya band. Seringkali unsur-unsur gaya zaman klasik digunakan dalam ibadah terutama pada bagian penyembahan. Teknik-teknik arpeggio atau semacam broken chord acapkali menghiasi performasi musikal di dalam ibadah Kristen. Penggunaan unsur-unsur klasik ini diakui atau tidak kenyataannya mampu menciptakan suasana yang lain, seperti suasana khikmad. Dengan kata lain, diakui atau tidak, unsur-unsur klasik seperti ini mampu menciptakan suasana ibadah yang mampu membawa jemaat pada hadirat Allah.

Teori yang digunakan dalam tulisan ini adalah teori perubahan sosial menurut Alvin Boskoff. Teori ini lazim dipakai untuk menganalisis sejarah perubahan yang terjadi di masyarakat, termasuk perubahan di bidang seni. Walaupun tidak secara eksplisit diungkapkan, menurut Boskoff, perubahan budaya (apapun bentuknya) senantiasa dipengaruhi oleh dua faktor, yakni faktor internal dan faktor eksternal. Faktor internal adalah faktor yang berasal dari komunitas yang bersangkutan-perubahan ini diprakarsai oleh oleh si pelaku budaya itu sendiri yang memang ingin berubah.

Teori Boskoff ini dibangun berdasarkan sebuah refleksi atas dampak Perang Dunia II, yakni mulai bermigrasinya hampir seluruh ras di dunia. Migrasi ini menciptakan urbanisasi dan perubahan sosial hampir di semua bangsa. Teori ini dibangun berdasarkan teori para sejarawan sebelumnya, yakni teori Robert E. Park dan Frederick J. Teggart. Migrasi telah menciptakan banyak perubahan signifikan dan krusial. For Park, as for Teggart, migration remains the process of social change. The formers tries to explain both the 'causes' and 'consequences' of migration. In short, Park treats migrations as 'internal' to 'transmitting' societies and 'external' to 'receiving' societies (Boskoff, tanpatahun, $\mathrm{p}$. 140-148). Inilah yang disebut dengan 'difusi kebudayaan'.

\section{Musik Pop}

Ibadah kharismatik tidak bisa dipisahkan dengan musik pop, oleh karena itu pembahasan mengenai musik menjadi penting. Istilah 'pop' dicetuskan oleh Lawrence Alloway, seorang pengamat seni rupa yang berkebangsaan Inggris. Pop adalah singkatan dari "populer" yang artinya "terkenal" (well-known). Istilah pop juga tak bisa dipisahkan dari budaya massa (mass culture). Budaya masif yang berumur pendek. Menurut Hauser 
(1979), "sifat dasar dari pop culture adalah kegelisahan dan kebosanan" (p. 580). Ciri-ciri musik pop yaitu lirik lagu, melodi dan musiknya relatif mudah diikuti, mudah dimengerti, singkat dan sederhana serta memanfaatkan inovasi teknologi untuk menghasilkan variasi baru pada tema yang ada. Genre musik ini dapat ditemui hampir diseluruh belahan dunia karena bisa diterima semua orang.

Musik populer pertama kali berkembang di Amerika Serikat pada tahun 1920. Rekaman musik pop pertama kali dibuat berdasarkan penemuan Thomas Edison, dibedakan dengan Musik Klasik, Musik Jazz, Musik Tradisional, Musik Blues, kemudian juga berkembang ke negara-negara lain di dunia. Alat musik yang dipakai dalam aliran musik pop disebut dengan alat musik combo band.

Adapun ciri-ciri dari musik pop yang dipakai di dalam musik gereja Kharismatik adalah penggunaan unsur-unsur musik yang sederhana. Penggunaan melodi yang mudah diterapkan dengan berbagai karakter lirik, fleksibel, mudah dipadukan dengan jenis lain seperti:

1. Penggunaan melodi yang mudah diterapkan dengan berbagai karakter lirik, fleksibel, mudah dipadukan dengan jenis lain,

2. Tanda birama yang dipakai kebanyakan tanda birama $4 / 4$ dan hanya beberapa yang menggunakan tanda $3 / 4$,

3. Syairnya cenderung menggunakan bentuk A B,

4. Penggunaan ritme/ irama yang sederhana, jarang didapati sinkopasi,

5. Penggunaan tempo sedang (moderato) dan cepat (allegro),

6. Penggunaan dinamika yang tidak terlalu kontras,

7. Pemakaian harmoni yang tidak rumit,

8. Penggunaan kadensa yang sederhana yakni perfect cadence.

9. Tanda birama yang dipakai kebanyakan tanda birama $4 / 4$ dan hanya beberapa yang menggunakan tanda $3 / 4$,

10. Syairnya cenderung menggunakan bentuk A B,

11. Penggunaan ritme/ irama yang sederhana, jarang didapati sinkopasi,

12. Penggunaan tempo sedang (moderato) dan cepat (allegro),

13. Penggunaan dinamika yang tidak terlalu kontras,

14. Pemakaian harmoni yang tidak rumit,

15. Penggunaan kadensa yang sederhana seperti kadens Sempurna. 
Berdasarkan pengamatan penulis, melihat bahwa unsur-unsur musik yang dipakai dalam tata cara ibadah pujian dan penyembahan di gereja (Katolik yang menggunakan unsur musik Gregorian) pada abad pertengahan yaitu banyaknya penggunaan unsur musik klasik sudah hilang atau tidak digunakan lagi dalam tata cara ibadah pujian dan penyembahan di gereja Kharismatik seperti:

1. Penggunaan mood (peralihan dinamika) yang beranekaragam dan kontras;

2. Pemakaian teknik arpeggio;

3. Memiliki pola ritme yang kaya dan fleksible;

4. Tekstur yang dipakai kebanyakan adalah tekstur yang homofon dan kadang bisa berubah menjadi tekstur polifon;

5. Memiliki melodi yang merdu, mudah diingat, bunyinya balance dan simetris karena sering dibuat dari dua frase yang sama panjangnya. Melodi yang kedua bisa dimulai seperti melodi yang pertama tapi diakhiri dengan lebih kondusif;

6. Perubahan dinamika yang bertahap dan lebih bright.

Secara sosiologis, musik pop tidak dapat dipisahkan dari aspek-aspek yang lain. Disadari atau tidak, suka atau tidak suka, musik pop mengalami perkembangan yang luar biasa dewasa ini. Perkembangan ini tampaknya tidak linear dengan saudaranya, musik serius (musik seni), yang masih 'berjalan di tempat' dan juga masih terkesan 'klasik'. Dieter Mack pernah mengungkapkan, “istilah 'musik populer' berhubungan dengan media massa, dan — mau tidak mau — berhubungan dengan unsur kuantitatif dari segi keuntungan uang". Itu berarti musik populer tidak dapat dipisahkan dari populer culture atau mass culture (budaya massa). Oleh karena itu, perihal mass culture akan dipaparkan terlebih dahulu agar pembahasan menjadi lebih komprehensif.

\section{Makna dan Karakter Mass Culture}

Mass culture atau populer culture adalah budaya yang melibatkan massa banyak. Herbert J. Gans mencatat, awalnya istilah ini merupakan kombinasi dari dua pemikiran (ide) di kalangan intelektual Jerman, yakni masse dan kultur. Masse merujuk pada golongan nonaristocratic - suatu golongan masyarakat di kawasan Eropa yang kurang berpendidikan. Lambat laun makna ini berkembang dan muncullah istilah mass (massa) yang sering dipakai untuk merujuk pada golongan (kelas) menengah ke bawah, miskin, orang kebanyakan (common people). Di dalam konteks budaya Jawa dapat setara dengan istilah 'wong cilik', inilah low culture. 
Sebaliknya, istilah kultur mengandung arti kebalikan (negasi) dari masse, yakni golongan terpelajar, bukan hanya terbatas pada bidang ilmu, tetapi juga cara berpikir, cara berperilaku, cara memandang (berperasaan) terhadap sesuatu. Istilah ini pada akhirnya mengacu pada sekelompok orang yang dianggap 'berbudaya' atau mereka 'yang telah dibudayakan'-mereka adalah golongan priyayi, golongan high culture. Istilah mass culture juga mengacu pada produk-produk yang digunakan oleh sebagian besar kaum yang 'kurang terdidik', yang bersifat massal. Di dalam bahasa Jerman, istilah mass culture dikenal juga dengan sebutan kitsch.

Secara historis tidak diketahui dengan pasti lahirnya istilah ini. Namun demikian, menurut catatan J. Gans, istilah mass culture lahir di awal abad ke 19 di Eropa. Gans menceritakan, pada saat itu di Eropa dunia politik dan kualitas pendidikan di masyarakat merosot tajam, bahkan mengarah kepada dekadensi moral, akibat tindakan golongan kelas atas (para bangsawan) yang memonopoli setiap aspek kehidupan (kebijakan) masyarakat, termasuk munculnya kebijakan penarikan pajak yang cukup tinggi. Namun demikian, kondisi masyarakat ternyata berbanding terbalik dengan perkembangan teknologi.

Penemuan demi penemuan muncul justru di tengah-tengah situasi ekonomi yang chaos itu. Kondisi ini tidak luput dari pantauan perusahaan-perusahaan besar, dan dengan mudah bisa mengambil keuntungan dari keadaan tersebut dengan memproduksi barangbarang kebutuhan secara massal dengan harga murah. Barang-barang itu bisa berupa kebutuhan rumah tangga, lukisan, buku, termasuk musik. Barang-barang tersebut sengaja dibuat secara massal untuk memenuhi permintaan pasar yang masif dan demi kepuasan pasar. Dari kondisi ini terciptalah masyarakat industri. Dalam masyarakat industri semua barang diproduksi semata-mata untuk mencari keuntungan.

Dalam perkembangannya, istilah mass culture mulai dihubungkan dengan makna peyoratif seperti yang diungkapkan J. Gans. Mass mulai diartikan sebagai massa/ kerumunan tanpa identitas/ jati diri yang jelas. Kehadiran mass bukan diatasnamakan secara personal atau individual, tidak pula mengatasnamakan suatu kelompok tertentu. Dari perkembangan makna tersebut, maka mass (massa) dapat diartikan sebagai 'kerumunan orang yang kurang berbudaya' (mob's lack of culture).

Dari uraiannya itu Gans (1974, p. 9-19) menarik simpulan bahwa hakikat 'massa' setidaknya memiliki tiga karakteristik, yakni (1) memiliki jumlah yang besar, (2) hubungan antarindividunya tidak terdapat hubungan organisatoris, dan (3) masing-masing individu memiliki latar belakang sosial yang berbeda-beda.Yang jelas istilah ini digunakan secara 
berbeda, pada saat yang berbeda, tempat, dan konteks yang berbeda, dan oleh orang-orang (komunitas) yang berbeda pula. Shuker (1994, p. 3) bahkan lebih menekankan bahwa istilah ini sebenarnya bukan semata-mata adjective (kata sifat), tetapi juga noun (kata benda). Ini mengandung konsekuensi bahwa pengertian atau makna 'popular' menjadi semakin luas.

Kenyataannya gereja karismatik menggunakan hal-hal yang sebetulnya secara historis, sosial, dan kultural berangkat dari sesuatu yang sekuler, bahkan berorientasi pada ide-ide kapitalistik. Lagu-lagu pop kenyataannya banyak dipakai dalam ibadah-ibadah gereja, bahkan menggunakan genre-genre lain yang bisa diperdebatkan dalam kaitannya dengan tujuan ibadah seperti hip hop, rap, rock, dan beberapa lagu untuk tarian (dance song).

\section{Musik Pop dan Industri}

Seperti telah disinggung dalam awal tulisan ini, istilah 'pop' berasal dari kata 'populer'. Suka Hardjana secara langsung mengatakan musik pop adalah "musik orang kebanyakan (common people), komersial, dan merupakan salah satu bentuk dari pengaruh kebudayaan Barat”. Oleh karena merupakan musik orang kebanyakan, maka musik pop sesungguhnya memiliki karakter yang spesifik pula yang tidak jauh dari karakter mass culture. Salah satu karakternya adalah adanya 'kemudahan' yang meliputi eksistensi musik ini. Karakter lain yang cukup penting adalah bersifat 'menghibur'. Dengan kata lain, oleh karena ditujukan untuk menghibur, maka segalanya dibuat mudah. Tidak pernah ada hiburan yang prosesnya jlimet, rumit, berbelit-belit.

Hiburan diciptakan agar orang bisa menikmati permainan yang terkandung di dalam hiburan itu, agar orang merasa senang tanpa harus melibatkan aktivitas pikiran yang sungguh-sungguh. 'Kemudahan' di dalam musik pop bisa meliputi (1) syair yang mudah dihafal dan tidak melibatkan pemikiran filsafat yang complicated serta bersifat langsung, (2) alunan melodi yang bersifat melodius, (3) harmoninya tidak terlalu rumit, misalnya cenderung menggunakan progresi akor yang sederhana, (4) menghentak keras, sehingga menggunakan alat musik band, yang tentu melibatkan penggunaan listrik, (5) bersifat fleksibel, artinya sebuah lagu bisa dengan mudah menyesuaikan diri dengan style apapun, (5) memiliki tempo yang (relatif) lebih bervariasi.

Pandangan semacam itu ternyata tidak selalu benar, sekurang-kurangnya menurut pandangan Adorno, lewat tulisan Andy Hamilton. Beberapa lagu klasik seperti karya 
Mozart dan Vivaldi bisa menjadi nge-pop, walaupun karya mereka bukan produk dari industri budaya. Karya mereka hanya masuk ke dalam kriteria 'populer'-Adorno menyebutnya sebagai 'popular classic'-, namun tidak di dalam karakter musik pop itu sendiri dalam arti genre. Namun demikian, kasus ini hanya sebagian kecil dari karya-karya klasik yang pernah ada. Hamilton (2007) menulisnya sebagai berikut:

\begin{abstract}
The culture industry is often assumed to embrace only popular music and arts, but this is a misinterpretation of Adorno's consept. It is also includes art music of the past that has been transformed into 'museum-art', as wellas 'moderate', non-modernist music of the present time that makes compromises in order to be accessible. For instance, Mozart's Symphony No.40 and Vivaldi's 'The Four Season' have become popular clasic and, hence, commodified Adorno would have marvelled at, and been appaled by, their appropriation by the mobile ring tone industry. But unlike commodified pop music, the work of Vivaldi and Mozart was not originally a product of the culture industry. (p. 172)
\end{abstract}

Akan tetapi Adorno dan Horkheimer melalui analisis Janet Wolff, sama-sama menyetujui adanya makna industri budaya di dalam jazz, walaupun secara umum dapat dikatakan karakter jazz dari sisi teknik permainan berbeda dengan pop. Filsuf Theodore W. Adorno (dikutip di Wolff, 1993, p. 89) menulis, “Jazz, like other products of what Adorno and Horkheimer called 'the culture industry' demans 'psychological regression' and denies individuality and individual needs, while pretending to acknowledge and gratify them."

Sifat lain yang juga melekat di dalam karakter musik pop adalah musik ini 'berumur pendek', tidak bertahan lama, atau mudah 'usang'. Di dalam blantika musik pop, tidak mengherankan jika selama hidupnya seorang pencipta lagu bisa menciptakan puluhan, bahkan ratusan lagu dalam satu tahun. Sebabnya adalah karena mudah diciptakan dan pasar selalu menuntut sesuatu yang baru secara cepat. Jika dihubungkan dengan pendapat Hauser, kenyataan ini tampaknya menjadi mudah untuk dipahami. Oleh karena musik pop merupakan budaya modern, maka karakternya membawa sifat bawaan dari masyarakatnya, yakni kebosanan (boredom) dan kegelisahan (reslessness). Menurut Hauser, kedua hal inilah yang mendasari lahirnya seni populer.

Secara ringkas ketika musik pop berada di televisi, ia tidak lepas dari urusan hiburan, kesenangan, dan dagang. Kenyataan seperti ini bagaimanapun membawa konsekuensi logis pada nilai estetisnya. Oleh karena memiliki paradigma hiburan, kesenangan, dan dagang, maka standar estetisnya juga berorientasi ke ketiga hal tersebut yakni dikembalikan kepada massa atau pasar. Pasarlah yang menentukan ukuran baik 
tidaknya sebuah lagu — artis manakah yang pantas diorbitkan. Penilaian estetis ini pada dasarnya bukan berasal dari ahli musik atau musikolog.

\section{Musik Klasik}

Istilah 'klasik' dalam khazanah musik Barat memiliki pengertian yang sangat beragam, bahkan musik tradisional seperti gamelan dalam konteks musik Indonesia juga merupakan musik klasik. Dalam tradisi musik Barat istilah 'musik klasik' memiliki pengertian sebagai berikut.

1. Klasik dipakai dalam hubungannya dengan kebudayaan dan keseniaan Yunani dan Roma Kuno (McNeill, 2003, p. 2).

2. Musik yang dibuat di atau berakar dari tradisi kesenian Barat, musik kristiani, dan musik orkestra, mencakup periode dari sekitar abad ke-9 hingga abad ke-21 (Kennedy, 2007).

3. Musik yang dipakai dalam sejarah musik Barat yang berlangsung selama sebagian besar abad ke-18 sampai dengan awal abad ke-19 - antara tahun 1750 dan 1820-yakni musik sesudah periode Barok, namun sebelum periode Romantik (Banoe, 2003, p. 87).

4. Musik lama, musik zaman lampau yang masih tetap bertahan di tengah tantangan berbagai musik diperbandingkan dengan zaman berikutnya, yaitu zaman romantik (Weber, Schumann, Mendelsshon) (Banoe, 2003; Kupferberg, 1985).

Akan tetapi secara musikologis, ada satu ciri yang terdapat di dalam musik klasik yang terdapat di dalam hampir semua komposisi di zaman klasik yakni adanya teknik arpeggio atau 'broken chord'. Inilah unsur estetetis yang paling kental di zaman klasik. Walaupun demikian teknik seperti ini masih sering dipakai, bahkan di dalam gereja karismatik sekalipun. Padahal menurut penulis unsur-unsur musik klasik memiliki nilai estetika dalam konteks musik seni yang mempermegah musik gereja itu sendiri dan menjadi barometer peradaban musik dunia yang justru cenderung ditinggalkan oleh musik di gereja kharismatik.

Walaupun demikian pada umumnya musik klasik yang sering dipahami adalah musik yang dipakai dalam sejarah musik Barat yang berlangsung selama sebagian besar abad ke-18 sampai dengan awal abad ke-19 - antara tahun 1750 dan 1820-yang berada pada periode sesudah Barok namun sebelum Romantik, dengan komponis yang paling terkenal dari zaman ini adalah Haydn (1732-1809), Wolfgang Amadeus Mozart (17561791) dan Ludwig van Beethoven (1770-1872) di masa awal karirnya. 


\section{Idiom Pop dalam Ibadah Karismatik}

Idiom-idiom pop ini kerapkali dipakai dalam ibadah karismatik. Penggunaan idiomidiom ini menjadi sangat khas karena dihadirkan dalam beberapa birama pada pengembangan tema, interlude dan beberapa di dalam pengembangan rekapitulasi, bahkan gaya ini sering juga muncul dalam tema-tema utama pada lagu-lagu yang bertempo allegro atau presto, walau tidak jarang juga hadir pada movement yang berprogres dari konsekuen dan antiseden. Di beberapa lagu gaya-gaya klasik muncul ketika terjadi modulasi dekat (short modulation) untuk mempertegas suatu bentuk perpindahan scale (tangga nada), yang biasanya bergerak dari akor mayor ke minor melodis.

Pada beberapa karya secara orkestratif, penggunaan arpeggio yang khas dalam gaya klasik berguna untuk mempertegas perpindahan bunyi dari alat satu ke alat yang lain yakni permainan keyboard ke beberapa alat tiup seperti saxophone dan flute. Tanpa arpeggio, kesan yang terjadi adalah patahan-patahan akor yang tentu sangat mengganggu nuansa estetisnya. Begitu pula pada perubahan-perubahan ritme yang dikembangkan oleh drum, akan sangat terbantu oleh broken chord yang dihadirkan dua birama sebelum memasuki tema kedua. Tampak jelas bahwa secara orkestratif teknik ini sangat membantu dan sebagai 'jembatan' pada suasana baru yang diciptakan oleh instrumen lain.

Peran broken chord menjadi sangat signifikan ketika bunyi instrumen dalam bass section memasuki akor minor melodis dan memasuki suasana baru yang lebih megah dengan ditampilkannya gerakan akor pada komposisi biola dan viola. Ketika semua alat musik berbunyi, dan nuansa polifoni tercipta, broken chord mulai menampakkan cirinya yang khas yakni menciptakan suasana allegretto yang menyeimbangkan beberapa karakter instrumen yang bersifat maskulin.

Suasana menjadi lebih jelas ketika peranan piano melengkapi keutuhan akor dengan ditampilkannya filler. Filler yang banyak menampilkan triad-triad pada akor mayor, memberikan kesan progresif yang khas pada bagian rekapitulasi dan memberikan suasana 'minor' dengan hadirnya instrumen cello yang walaupun di dalam skala mayor tetapi terkesan menjadi minor harmonis.

Dari analisis di atas jelas bahwa penggunaan gaya-gaya klasik memberikan nuansa baru bagi nilai estetis big band, dengan terpengaruhnya tempo dan dinamika. Peran ini sangat penting karena nilai-nilai estetis yang dibangun tidak hanya bersifat statis tetapi dinamis. Bagi sebagian besar tradisi musik kharismatik, pengayaan dengan menggunakan gaya ini memang kurang lazim akan tetapi kenyataannya gaya-gaya klasik memiliki 
kemampuan bagi pengembangan permainan, terutama dalam hal tempo dan dinamika, yang pada gilirannya mempengaruhi suasana di dalam suatu ibadah.

\section{Kesimpulan}

Berdasarkan penjelasan dan analisis yang sudah dijelaskan, maka cakupan mengenai pembahasan teori dan analisis menghasilkan kesimpulan yakni gaya klasik di dalam musik yang digunakan pada ibadah kharismatik menduduki peran yang sangat penting. Kehadiran/ pemakaian gaya ini sangat mempengaruhi suasana estetis yang diciptakan selama permainan musik berlangsung, oleh karena karakter arpeggios gaya klasik yang cenderung bertempo andante, andantino, allegretto, dan moderato, maka pemakaian gaya-gaya tersebut lebih cocok dipakai pada bagian penyembahan. Suasana yang dihasilkan oleh tempo ini secara psikologis, akan menciptakan suasana khidmat dan mampu membawa jemaat pada hadirat Allah dalam sebuah peribadahannya.

Secara musikologis, arpeggios mampu memberikan pengaruh dan ruang bagi beberapa instrumen untuk dimainkan secara sederhana sehingga memberi nuansa yang lain, yang berbeda pada waktu instrumen digunakan pada sesi pujian. Broken chord pada instrumen piano dan gitar memberikan efek yang memiliki nilai estetis yang anggun, namun megah sesuai dengan karakteristik musik zaman klasik. Karakteristik ini akan lebih mendukung suasana penyembahan yang lebih sempurna, yang sudah barang tentu membantu jemaat dalam 'bertemu' dengan Allah yang kudus.

Ibadah kharismatik memang lebih dekat dengan model contemporary music yang lebih banyak menggunakan alat musik band, akan tetapi penggunaan gaya klasik dapat lebih memperkaya nuansa estetis di dalam ibadah. Pada ruang lingkup musik terdapat berbagai dinamika yang mempengaruhi suasana ibadah dengan menggunakan gaya klasik ini ibadah lebih bersifat dinamis dan jauh dari membosankan. Hal tersebut disebabkan oleh penggunaan chord-chord yang cenderung kaku menjadi lebih fleksibel dan dapat lebih mudah diterima oleh jemaat, sehingga jemaat lebih dapat mengikuti ibadah dengan baik.

Permainan musik yang lebih banyak mengunakan feeling di dalam contemporary music akan terlihat lebih 'tertib' dengan menggunakan gaya klasik yang umumnya menggunakan partitur sebagai media bermain secara bersama-sama. Permainan musik dengan menggunakan partitur akan lebih memungkinkan bagi pemain untuk lebih tepat dalam menerapkan tempo, irama, dan dinamika. Kebersamaan penggunaan alat musik ini secara musikologis akan membuat suasana ibadah menjadi lebih khidmat namun meriah. 


\section{Kepustakaan}

Albineno, Ch. J.L. (1976). Gerakan Pentakosta dan Gerakan Pentakosta Baru (Gerakan Kharismatik). Jakarta: BPK Gunung Mulia.

. (2005). Unsur-Unsur Liturgia Yang Dipakai Oleh Gereja-Gereja di Indonesia. Jakarta: BPK Gunung Mulia.

Banoe, Pono. (2003). Kamus Musik. Yogyakarta: Kanisius.

Boskoff, Alvin. (tanpa tahun). Recent Theory of Social Change. Dalam Boskoff, Alvin dan Cahnman, Werner J. (Eds.), Sociology and Hisory: Theory and Reasearch. London: The Free Press of Glencoe.

Gans, Herbert J. (1974). Popular Culture and High Culture. New York: Basic Books, Inc., Publisher.

Hamilton, Andy. (2007). Aesthetics and Music. British: Continuum International Publishing Group.

Hauser, Arnold. (1979). The Sociology of Art. Chicago: University of Chicago Press.

John, Meyendorff. (1982). The Byzantine Legacy in the Orthodoox Church. USA: St. Vladimir's Seminary Press.

Karl, Rahner. (1975). Encyclopedia of Theology: A Concise Sacramentum Mundi. USA: Continuum International Publishing Inc.

Kennedy, Michael. (2007). The Oxford Concise Dictionary of Music. Oxford: Oxford University Press.

Kupferberg, Herbert. (1985). The Book of Classical Music Lists. New York: Facts on File Publications.

Matthew, Heato. (2008). A History of Nigeria. USA: Cambridge University Press.

McNeill, Rhoderick J. (2003). Sejarah Musik 2. Jakarta: Gunung Mulia.

Samuel, Wilfred J. (2006). Kristen Kharismatik. Jakarta: BPK Gunung Mulia.

Saragih, Winardo. (1976). Misi Musik. Yogyakarta: Andi Offset.

Schemann, Alexander. (1965). Sacred and Orthodoxy. New York: Herder and Herder.

Sevy, Albert. (1975). Music in the Medieval World. New Jersey: Prentice-Hall, Inc.

Shuker, Roy. (1994). Understanding Popular Music. London: Routledge .

Sugiri S., L. (2006). Gerakan Kharismatik Apakah Itu?. Jakarta: BPK Gunung Mulia.

White, James F. (1990). Introduction to Christian Worship. USA: Abingdon Press. . (2002). Pengantar Ibadah Kristen. Jakarta: Gunung Mulia. 